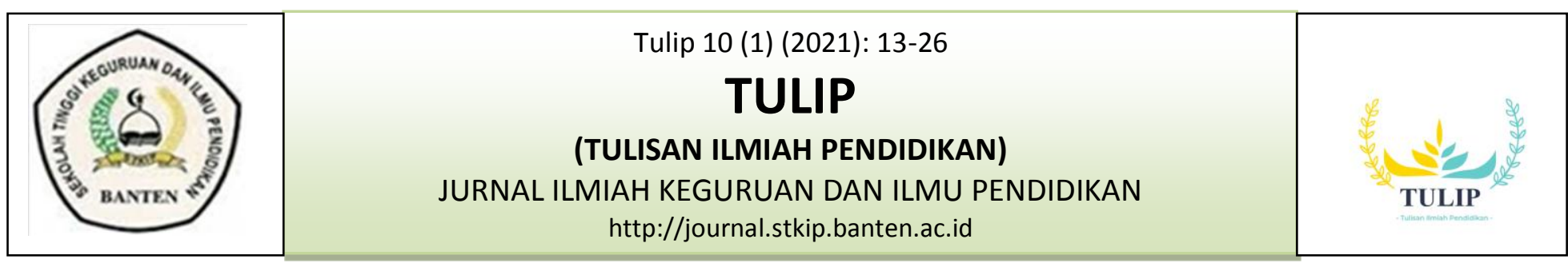

\title{
PENGARUH MODEL PEMBELAJARAN KOOPERATIF TIPE THINK PAIR SHARE TERHADAP KEMAMPUAN PEMECAHAN MASALAH MATEMATIKA SISWA
}

\author{
Fatmawati $^{1}$ dan Hidayatuloh ${ }^{2}$ \\ ${ }^{1}$ Sekolah Tinggi Keguruan dan Ilmu Pendidikan Banten \\ ${ }^{2}$ Mahasiswa Pendidikan Matematika \\ Ayu.fatma1706@gmail.com¹ dan hidayatullah@gmail.com² \\ Artikel Kooperati Tipe Think Pair Share \\ Penerima: Desember, 2020 \\ Diterima: Januari, 2021 \\ Dipublikasikan: Maret, 2021
}

\begin{abstract}
This study aims to analyze the influence of the cooperative learning model type think pair share on the mathematics problem solving ability of grade VIII at MTs Alkhaeriyah Pipitan Serang City. This research is a quantitative survey method. The research sample consisted of 28 students. The instrument used was closed questionnaires to measure students responses to the cooperative learning model think pair share and a test to measure mathematical problem solving abilites. The analysis technique used is correlation analysis and regression analysis. The results of the correlation analysis obtained a correlation coefficient of 0,522. The results of the regression analysis obtained a value of 9,72 and the at a significant level of $5 \%$ or 0,05 the is 4,22. Because so $H_{0}$ rejected, with a correlation coefficient of 0,522 So, it can be concluded that there is a significant effect of the cooperative learning model type think pair share on the mathematics problem solving ability of grade VIII at MTs Al-Khaeriyah Pipitan Serang City by 27,25\%
\end{abstract}

Keywords : Cooperative Learning Model Type Think Pair Share, Problem Solving

\begin{abstract}
ABSTRAK
Penelitian ini bertujuan untuk menganalisis pengaruh model pembelajaran kooperatif tipe think pair share terhadap kemampuan pemecahan masalah matematika siswa kelas VIII MTs AlKhairiyah Pipitan Kota Serang. Penelitian ini merupakan penelitian kuantitatif metode survei. Sampel penelitian berjumlah 28 siswa. Instrumen yang digunakan adalah angket tertutup untuk mengukur respon siswa terhadap model pembelajaran kooperatif tipe think pair share dan tes untuk mengukur kemampuan pemecahan masalah matematika. Teknik analisis data yang digunakan adalah analisis korelasi dan analisis regresi. Hasil analisis korelasi diperoleh koefisien korelasi sebesar 0,522. Hasil analisis regresi diperoleh nilai sebesar 9,72 dan pada taraf signifikan sebesar 5\% atau 0,05 diperoleh sebesar 4,22. Karena maka $\mathrm{H}_{0}$ ditolak, dengan koefisien korelasi sebesar 0,522 dapat disimpulkan bahwa terdapat pengaruh yang signifikan model pembelajaran kooperatif tipe think pair share terhadap kemampuan pemecahan masalah matematika siswa kelas VIII MTs Al-Khairiyah Pipitan Kota Serang sebesar 27,25\%.
\end{abstract}

Kata Kunci : Model Pembelajaran Kooperatif Tipe Think Pair Share, Pemecahan Masalah 


\section{PENDAHULUAN}

Pendidikan merupakan faktor yang sangat penting untuk meningkatkan Sumber Daya Manusia (SDM) yang selalu ada masalah didalamnya. Dimana pendidikan dimaknai sebagai proses mengubah tingkah laku anak didik agar menjadi manusia dewasa yang mampu hidup mandiri dan sebagai anggota masyarakat dalam lingkungan alam sekitar dimana individu itu berada (Syaiful Sagala, 2012). Untuk memajukan kehidupan mereka itulah, maka pendidikan menjadi sarana utama yang perlu dikelola, secara sistematis dan konsisten berdasarkan berbagai pandangan teoritikal dan praktikal sepanjang waktu sesuai dengan kebutuhan hidup manusia itu sendiri (Fuad Ihsan, 2011).

Kemampuan pemecahan masalah merupakan salah satu keterampilan proses yang perlu dimiliki siswa melalui proses pembelajaran matematika. Dalam pembelajaran matematika, pemecahan masalah merupakan komponen penting dari pendidikan matematika karena memiliki peran praktis untuk individu dan masyarakat. Sehingga pemecahan masalah merupakan bagian dari kurikulum yang sangat penting bagi siswa untuk mempelajari kemampuan pemecahan masalah dan guru perlu dilengkapi dengan strategi pedagogis yang diperlukan untuk secara efektif mengajarkan keterampilan ini (Kartika Handayani Z, 2017).

Pentingnya kemampuan pemecahan masalah dalam matematika ditegaskan oleh Branca dalam Mansyur diantaranya sebagai berikut :

1. kemampuan meyelesaikan masalah merupakan tujuan umum pengajaran matematika.

2. Penyelesaian masalah yang meliputi metode, prosedur dan strategi merupakan proses inti dan utama dalam kurikulum matematika.
3. Penyelesaian masalah merupakan kemampuan dasar dalam belajar matematika (Zulfikar mansyur, 2014).

Kurikulum Tingkat Satuan

Pendidikan (2006) yang

disempurnakan pada kurikulum 2013, mencantumkan tujuan pembelajaran matematika sebagai berikut:

1. Memahami konsep matematika, menjelaskan keterkaitan antar konsep dan mengaplikasikan konsep atau algoritma secara luwes, akurat, efisien, dan tepat dalam pemecahan masalah.

2. Menggunakan penalaran pada pola dan sifat, melakukan manipulasi matematika dalam membuat generalisasi, menyusun bukti, atau menjelaskan gagasan dan pernyataan matematika.

3. Memecahkan masalah yang meliputi kemampuan memahami masalah, merancang model matematika, menyelesaikan model dan menafsirkan solusi yang diperoleh.

4. Mengkomunikasikan gagasan dengan symbol, tabel, diagram, atau media lain untuk memperjelas keadaan atau masalah.

5. Memiliki sikap menghargai kegunaan matematika dalam kehidupan, sikap rasa ingin tahu, perhatian, dan minat dalam mempelajari matematika, serta sikap ulet dan percaya diri dalam pemecahan masalah (Ahmad Rifai, 2016).

Berdasarkan hal tersebut, ternyata dalam KTSP pun dicantumkan bahwa memecahkan masalah adalah salah satu tujuan dari pembelajaran matematika. Hal ini membuktikan bahwa kemampuan pemecahan masalah benar-benar memiliki arti penting dalam kemajuan pendidikan.

Namun kenyataan yang terjadi dilapangan kemampuan pemecahan masalah matematika siswa masih rendah, hal ini terlihat saat guru memberikan soal yang berbeda dengan contoh siswa masih kesulitan, hanya sebagian kecil saja yang 
mampu menjawab dengan benar. Hal ini diungkapkan oleh salah satu Guru Matematika di MTs Al-Khaeriyah Pipitan. Rendahnya kemampuan pemecahan masalah matematika ini bisa jadi ada kaitannya dengan pendekatan pembelajaran yang dilakukan oleh guru. Hasil penelitian yang dilakukan Slamet dalam Ali menyatakan bahwa umumnya proses pembelajaran matematika yang ditemuinya masih dilakukan secara konvensional, drill bahkan ceramah. Menurutnya proses pembelajaran seperti ini hanya menekankan pada tuntutan pencapaian kurikulum ketimbang mengembangkan kemampuan belajar siswa (Ali Rohali, 2018). Pembelajaran seperti ini akan membuat siswa pasif dan siswa tidak bisa mengembangkan kemampuan berfikirnya terutama dalam memecahkan masalah matematika. Oleh sebab itu, perlu dicari model, strategi maupun pendekatan pembelajaran yang mampu mengembangkan kemampuan pemecahan masalah matematika.

$$
\text { Dengan penerapan model }
$$

pembelajaran yang tepat akan membuat suasana kelas aktif, menyenangkan, kreatif, baik dalam pembelajaran individual maupun kelompok memungkinkan siswa dalam kelas berpartisipasi dalam mengkomunikasikan gagasannya. Suasana kelas tersebut dapat terwujud apabila guru aktif mengevaluasi diri dalam hal model pembelajaran yang dipakai, alat / bahan dan evaluasi yang digunakan (Agus Margono, dkk, 2017).

Salah satu model pembelajaran yang dapat mengembangkan kemampuan pemecahan masalah matematika adalah model pembelajaran think pair share. Dengan cara berkelompok, siswa dapat mengerjakan soal-soal atau permasalahan dengan kerjasama dan kegiatan ini dijadikan sebagai sarana untuk melatih kemandirian. Selain itu dengan model pembelajaran think pair share ini dapat mengoptimalkan aktivitas siswa saat pembelajaran, sehingga siswa lebih berperan aktif dalam pembelajaran, dengan kerja kelompok siswa akan lebih banyak mendapatkan masukan-masukan dalam memecahkan masalah, yang pada akhirnya siswa akan mampu secara mandiri dalam memecahkan masalah.

Berdasarkan uraian diatas, rumusan masalah dalam penelitian ini adalah "Apakah Model Pembelajaran Kooperatif Tipe Think Pair Share Berpengaruh Terhadap Kemampuan Pemecahan Masalah Matematika Siswa Kelas VIII di MTs Al-Khairiyah Pipitan?"

Sesuai permasalahan diatas Tujuan Dalam Penelitian Ini Adalah "Untuk Menganalisis Pengaruh Model Pembelajaran Kooperatif Tipe Think Pair Share Terhadap Kemampuan Pemecahan Masalah Matematika Siswa Kelas VIII di MTs Al-Khairiyah Pipitan Kota Serang”.

1. Manfaat Teoritis

Secara umum hasil penelitian ini diharapkan mampu memberi masukkan terhadap pembelajaran matematika utamanya dalam meningkatkan kemampuan pemecahan matematika siswa. Secara khusus penelitian ini mampu memberikan konstribusi terhadap strategi pembelajaran matematika.

2. Manfaat Secara Praktis

a. Bagi peneliti Menjadi reverensi atau acuan bagi peneliti untuk melakukan perbaikan dalam kegiatan belajar mengajar di kelas ketika nanti menjadi guru mata pelajaran.

b. Bagi Siswa Memperoleh pembelajaran yang lebih aktif dan menarik, membantu siswa dalam bersosialisasi baik dengan siswa lain ataupun dengan guru dan dapat meningkatkan kemampuan pemecahan masalah matematika sehingga tujuan pembelajaran tercapai.

c. Bagi Sekolah Memberikan masukan dalam strategi pembelajaran yang digunakan untuk mengembangkan proses pembelajaran yang mampu 
meningkatkan kemampuan pemecahan masalah matematika siswa.

\section{LANDASAN TEORI}

\section{Hakikat Model Pembelajaran Kooperatif}

Istilah model pembelajaran sering dimaknai sama dengan pendekatan pembelajaran. Sebenarnya model pembelajaran mempunyai makna yang lebih luas dari pada makna pendekatan, strategi, metode maupun teknik.Karena Model pembelajaran adalah rangkaian dari pendekatan, strategi, metode, teknik, dan taktik pembelajaran.Model pembelajaran pada dasarnya merupakan bentuk pembelajaran yang tergambar dari awal sampai akhir yang disajikan secara khas oleh guru. Dengan kata lain, model pembelajaran merupakan bungkus atau bingkai dari penerapan suatu pendekatan, strategi, metode, dan teknik pembelajaran (Nurul Badriaytul Muthoharoh, 2017).

Joyce dan weill dalam Huda mendeskripsikan model pembelajaran sebagai rencana atau pola yang dapat digunakan untuk membentuk kurikulum mendesain materi-materi instruksional, dan memandu roses pembelajaran diruang kelas atau di setting yang berbeda (Miftahul Huda, 2017) Sejalan dengan itu Sujana juga menyatakan bahwa Model pembelajaran merupakan suatu rancangan dalam melaksanakan kegiatan pembelajaran yang disusun secara sistematis untuk mencapai tujuan pembelajaran yang telah ditetapkan (Shanty Della Setiasih, dkk, 2016).

Berdasarkan pengertian diatas dapat ditarik kesimpulan bahwa model pembelajaran merupakan bentuk representasi dari pendekatan, strategi, metode dan teknik pembelajaran yang disusun secara sistematis untuk mencapai tujuan pembelajaran
Secara umum pembelajaran kooperatif dianggap lebih diarahkan oleh guru, dimana guru menetapkan tugas dan pertanyaan-pertanyaan serta menyediakan bahan-bahan dan informasi yang dirancang untuk membantu siswa menyelesaikan masalah yang dimaksud (Agus Suprijono, 2017).

Menurut Abdulhak menyebutkan bahwa pembelajaran kooperatif dilaksanakan melalui sharing proses antara peserta belajar, sehingga dapat mewujudkan pemahaman bersama diantara peserta belajar itu sendiri (Rusman, 2016) Pembelajaran kooperatif juga merupakan model pembelajaran yang menekankan aktivitas kolaboratif siswa dalam belajar yang memecahkan masalah secara kolektif kolaboratif (Eveline Siregar dan Hartini Nara, 2010).

Robert E Slavin mengemukakan tujuan yang paling penting dari model pembelajaran kooperatif adalah untuk memberikan para siswa pengetahuan, konsep, kemampuan, dan pemahaman yang mereka butuhkan supaya bisa menjadi anggota masyarakat yang bahagia dan memberikan kontribusi. Wisenbaken mengemukakan bahwa tujuan model pembelajaran kooperatif adalah menciptakan norma-norma yang proakademik di antara para siswa, dan normanorma pro-akademik memiliki pengaruh yang amat penting bagi pencapaian siswa (Sahurikhorot, 2015)

Dari pendapat diatas dapat disimpulkan bahwa model pembelajaran kooperatif merupakan model pembelajaran berkelompok yang membuat siswa saling bekerja sama satu sama lain dalam pemecahan masalah, dimana siswa diberikan kesempatan yang luas untuk menemukan dan menerapkan ide-ide mereka sendiri, serta kelompok dikatakan berhasil, apabila setiap angota kelompok secara individu memiliki pemahaman yang sama. 


\section{Hakikat Model Pembelajaran Think Pair Share}

Menurut Ariz Think Pair Share adalah suatu model pembelajaran kooperatif yang memberi siswa waktu untuk berfikir dan merespon serta saling bantu satu sama lain. Pembelajaran ini melatih siswa berani berpendapat dan menghargai pendapat teman (Ariz Shoimin, 2013).

Azlina dalam jurnal Andi Khaerunisa dkk, yang menyatakan bahwa Think Pair Share (TPS) merupakan jenis pembelajaran kooperatif yang dirancang dalam bentuk diskusi yang dapat meningkatkan kemampuan berpikir siswa, keterampilan berkomunikasi siswa dan mendorong partisipasi siswa dalam kelas (Andi Khaerunnisa, dkk, 2017).

Sedangkan Agus Suprijono menyatakan bahwa Think Pair Share seperti namanya "Thinking" pembelajaran ini diawali dengan guru mengajukan pertanyaan atau isu terkait dengan pelajaran untuk difikirkan oleh peserta didik. Guru memberi kesempatan kepada mereka memikirkan jawabannya. Selanjutnya "Pairing", pada tahap ini guru meminta peserta didik berpasangpasangan. Diharapkan diskusi ini dapat memperdalam makna dari jawaban yang telah dipikirkannya intersubjektif dengan pasangannya. Hasil diskusi intersubjektif di tiap-tiap pasangan hasilnya dibicarakan dengan pasangan seluruh kelas. Tahap ini dikenal dengan "Sharing". Dalam kegiatan ini diharapkan terjadi tanya jawab yang mendorong pada pengkonstruksian pengetahuan secara integratif. Peserta didik dapat menemukan struktur dari pengetahuan yang dipelajarinya (Agus Suprijono, 2017).

Berdasarkan pengertian para ahli diatas peneliti berkesimpulan bahwa model pembelajaran think pair share merupakan model pembelajaran kooperatif yang melalui tahap thinking, pairing dan sharing, dimana pembelajaran ini memberikan siswa waktu untuk berfikir dan merespon serta saling bantu satu sama lain untuk mencapai tujuan pembelajaran. Pembelajaran ini juga melatih siswa untuk berani berpendapat dan menghargai pendapat teman.

Menurut Nurhadi dalam jurnal Susanti menyatakan bahwa tujuan dari think pair share adalah untuk meningkatkan penguasaan akademik, dan mengajarkan keterampilan sosial (Susanti, 2017).

Menurut Aris langkah-langkah Think Pair Share seperti berikut ini:

1. Tahap satu, think (berfikir) pada tahap ini guru memberikan pertanyaan yang berkaitan dengan materi pelajaran. Proses TPS dimulai pada saat ini, yaitu guru mengemukakan pertanyaan yang menggalakkan berfikir keseluruh kelas. Pertanyaan ini hendaknya berupa pertanyaan terbuka yang memungkinkan dijawab dengan berbagai macam jawaban.

2. Tahap dua, pair (berpasangan). Pada tahap ini siswa berfikir secara individu. Guru meminta kepada siswa untuk berpasangan dan mulai memikirkan pertanyaan atau masalah yang diberikan guru dalam waktu tertentu. Lamanya waktu ditetapkan berdasarkan pemahaman guru terhadap siswa. Siswa disarankan untuk menulis jawaban atau pemecahan hasil pemikirannya.

3. Tahap tiga, share (berbagi) Pada tahap siswa secara individu mewakili kelompok atau berdua maju bersama untuk melaporkan hasil diskusinya keseluruh kelas.pada tahap terakhir ini siswa seluruh kelas akan memperoleh keuntungan dalam bentuk mendengarkan berbagai ungkapan mengenai konsep yang sama dinyatakan dengan cara yang berbeda oleh individu yang berbeda (Ariz Shoimin, 2013).

Setiap model pembelajaran pasti memiliki kelebihan yang membedakannya dengan model pembelajaran lain. Kelebihan yang dimiliki oleh model 
pembelajaran think pair share juga merupakan salah satu alasan dipilihnya model pembelajaran tersebut untuk mengatasi masalah pembelajaran yang berkembang di dalam kelas karena memiliki kekhasan tertentu.

Namun dibalik setiap kelebihan pasti ada kekurangan yang dimunculkan. Sebaik apapun suatu model pembelajaran pasti memiliki titik kelemahan, namun bukan berarti kelemahan ini yang ditonjolkan melainkan kelebihannyalah yang semestinya ditonjolkan. Kekurangan suatu model pembelajaran cukup dijadikan bahan evaluasi atas pelaksanaan suatu kegiatan pembelajaran.

Adapun kelebihan model pembelajaran think pair share yaitu :

1. Think pair share mudah diterapkan di berbagai jenjang pendidikan dan dalam setiap kesempatan.I

2. Menyediakan waktu berfikir untuk meningkatkan kualitas respon siswa.

3. Siswa menjadi lebih aktif dalam berfikir mengenai konsep dalam mata pelajaran.

4. Siswa lebih memahami tentang konsep topik pembelajaran selama diskusi.

5. Siswa dapat belajar dari siswa lain.

6. Setiap siswa dalam kelompoknya mempunyai kesempatan untuk berbagi atau menyampaikan idenya (Ariz Shoimin, 2013).

Nidhomudin

menyebutkan

Beberapa kelemahan model pembelajaran kooperatif tipe think pair share sebagai berikut :

1. Peralihan dari seluruh kelas ke kelompok kecil dapat menyita waktu pembelajaran yang berharga. Untuk itu guru harus dapat membuat perencanaan yang seksama sehingga dapat meminimalkan jumlah waktu yang terbuang.

2. Banyak kelompok yang melapor dan perlu dimonitor.

3. Ketidaksesuaian antara waktu yang direncanakan dengan pelaksanaannya.
4. Mengubah kebiasaan siswa belajar dari yang dengan cara mendengarkan ceramah diganti dengan belajar berfikir memecahkan masalah secara kelompok, hal ini merupakan kesulitan sendiri bagi siswa.

5. Jumlah siswa yang ganjil berdampak pada saat pembentukan kelompok, karena ada satu siswa tidak mempunyai pasangan.

6. Siswa yang kemampuan pemechannya rendah ada kemungkinan ia akan menggantungkan pada pasangan (Nidhomuddin, 2013)

\section{Hakikat Kemampuan Pemecahan Masalah Matematika}

Menurut Stephen P.Robin dalam jurnal Indra menyatakan kemampuan adalah kapasitas seorang individu untuk mengerjakan berbagai tugas dalam suatu pekerjaan (Indra Sakti, 2011). Sedangkan menurut Haryono dalam Ahmad menyatakan kemampuan adalah suatu kesanggupan, kecakapan, kompetensi seseorang yang secara sadar yang menghasilkan nilai atau suatu kepandian untuk menciptakan sesuatu dengan yang dikehendaki (Ahmad Yamin Hasibuan, 2016). Kemampuan yang akan dicapai dalam pembelajaran adalah tujuan pembelajaran (Dimyati dan Mudjiono, 2013).

Suryo menyatakan masalah sebagai suatu situasi atau kondisi (dapat berupa pertanyaan/ issu) yang disadari dan memerlukan suatu tindakan pemecahan, serta tidak segera tersedia suatu cara untuk mengatasi situasi itu (Suryo Widodo, 2017). Pengertian "tidak segera" dalam hal ini adalah bahwa pada saat situasi tersebut muncul, diperlukan suatu usaha untuk mendapatkan cara yang dapat digunakan mengatasinya.

Hayes mendukung pendapat tersebut dengan mengatakan bahwa suatu masalah merupakan kesenjangan antara keadaan yang sekarang dengan tujuan yang akan dicapai, sedangkan kita tidak 
mengetahui apa yang harus dikerjakan untuk mencapai tujuan tersebut (Asep Sahrudin, 2016).

Dalam jurnal Suryo, Polya membagi masalah menjadi dua macam, yaitu sebagai berikut:

1. Masalah untuk menemukan, yang bertujuan untuk menemukan objek (sasaran) yang pasti atau masalah yang ditanyakan. Bagian utama dari masalah adalah apakah yang ditanyakan, apa saja yang diketahui dan bagaimana syaratnya. Ketiga bagian utama tersebut sebagai landasan untuk dapat menyelesaikan masalah jenis ini.

2. Masalah untuk membuktikan adalah untuk menunjukkan pernyataan itu benar atau salah, Kita perlu menjawab pertanyaan: "apakah pernyataan tersebut benar atau salah?", menjawab pertanyaan dengan membuktikan pernyataan tersebut benar atau salah tetapi tidak kedua-duanya. Bagian utama masalah ini jika masalahnya merupakan masalah matematika adalah hipotesis dan konklusi dari suatu teorema yang harus dibuktikan kebenarannya (Suryo Widodo, 2017).

Menurut Made pemecahan masalah dipandang sebagai suatu proses untuk menemukan kombinasi dari sejumlah aturan yang dapat diterapkan dalam upaya mengatasi situasi yang baru (Made Wena, 2013)

Sementara itu menurut Polya dalam jurnal Siti Komariyah menyatakan bahwa pemecahan masalah sebagai usaha mencari jalan keluar dari suatu kesulitan (Siti Komariyah, dkk, 2018). Sehingga, kalau seorang peserta didik dihadapkan pada suatu masalah, pada akhirnya mereka bukan hanya sekedar memecahkan masalah, tetapi juga belajar sesuatu yang baru (E. Mulyasa, 2016).

Polya solusi soal pemecahan masalah memuat empat langkah fase penyelesaian, yaitu:

1. Memahami masalah.
Langkah ini sangat penting dilakukan sebagai tahap awal dari pemecahan masalah agar siswa dapat dengan mudah mencari penyelesaian masalah yang diajukan. Siswa diharapkan dapat memahami kondisi soal atau masalah yang meliputi: mengenali soal, menganalisis soal, dan menterjemahkan informasi yang diketahui dan ditanyakan pada soal tersebut.

2. Merencanakan penyelesaian.

Masalah perencanaan ini penting untuk dilakukan karena pada saat siswa mampu membuat suatu hubungan dari data yang diketahui dan tidak diketahui, siswa dapat menyelesaikannya dari pengetahuan yang telah diperoleh sebelumnya.

3. Menyelesaikan masalah sesuai rencana Langkah perhitungan ini penting dilakukan karena pada langkah ini pemahaman siswa terhadap permasalahan dapat terlihat. Pada tahap ini siswa telah siap melakukan perhitungan dengan segala macam yang diperlukan termasuk konsep dan rumus yang sesuai.

4. Melakukan pengecekan kembali terhadap semua langkah yang telah dikerjakan.

Pada tahap ini siswa diharapkan berusaha untuk mengecek kembali dengan teliti setiap tahap yang telah ia lakukan. Dengan demikian, kesalahan dan kekeliruan dalam penyelesaian soal dapat ditemukan (Zulfikarmansyur, 2014)

Matematika dalam Kamus Besar bahasa Indonesa adalah sebagai ilmu tentang bilangan, hubungan antar bilangan dan prosedur operasional yang digunakan dalam penyelesaian mengenai bilangan (Abdul Halim Fathani, 2012). Sedangkan menurut Susanto menjelaskan bahwa matematika merupakan salah satu disiplin ilmu yang dapat meningkatkan kemampuan berpikir dan berargumentasi (Ahmad Susanto, 2016). 
Berdasarkan uraian diatas dapat disimpulkan bahwa pada dasarnya kemampuan pemecahan masalah dalam matematika adalah kemampuan siswa dalam menyelesaikan masalah matematika dengan memperhatikan proses menemukan jawaban berdasarkan langkah-langkah pemecahan masalah.

\section{METODOLOGI PENELITIAN}

Penelitian ini menggunakan metode penelitian survei, metode penelitian survei termasuk dalam metode penelitian kuantitatif. Metode kuantitatif dapat diartikan sebagai metode penelitian yang berlandaskan pada filsafat positivisme, metode ini digunakan untuk meneliti pada populasi atau sampel tertentu, teknik pengambilan sampel pada umumnya dilakukan secara random, pengumpulan data menggunakan instrument penelitian, analisis data bersifat kuantitatif/statistik dengan tujuan untuk menguji hipotesis yang telah ditetapkan (Sugiyono, 2017)

Metode survei merupakan suatu teknik pengumpulan informasi yang dilakukan dengan cara menyusun daftar pertanyaan yang di ajukan kepada responden. Pada metode survei peneliti mengamati karakteristik ataupun hubungan sebab-akibat antar variabel tanpa adanya intervensi peneliti (Karunia Eka Lestari dan Mokhammad Ridwan Yudhanegara, 2017).

Desain penelitian menggunakan paradigma sederhana, yakni paradigma yang terdiri atas satu variabel independen dan satu variabel dependen (Sugiyono, 2017)

Tahapan pada penelitian survei ini diawali dengan peneliti memberikan video pembelajaran yang berkaitan dengan model pembeljaran kooperatif tipe think pair share dan materi lingkaran kemudian dilakukan dengan memberikan tes dan juga angket.

Penelitian dilakukan di MTs AlKhaeriyah Pipitan Kota Serang dan penelitian ini berlangsung dari tanggal 5-
28 Juli 2020. Target populasi dalam penelitian ini adalah seluruh siswa kelas VIII MTs Al-Khaeriyah Pipitan sejumlah 140 siswa. Sempel dipilih dengan teknik simple random sampling dimana masingmasing kelas dipilih sebanyak $20 \%$ sehingga terpilih sempel sejumlah 28 siswa.

Teknik pengumpulan data dalam penelitian ini meliputi data primer berupa angket tertutup untuk mengukur variabel model pembelajaran kooperatif tipe think pair share sejumlah 20 butir dan tes uraian untuk mengukur variabel kemampuan pemecahan masalah matematika sejumlah 6 butir soal data sekunder berupa dokumentasi selama penelitian.

Teknik analisis data meliputi deskripsi data yang meliputi skor tertinggi, skor terendah, rata-rata, median, modus, varians, simpangan baku dan pengkategorian.

penentuan kategori didasarkan pada tabel penentuan kategori menurut Handoko Riwidikdo dalam Ratna (Ratna Latifah Jati, 2015), yaitu sebagai berikut :

Tabel 1.

Tabel Menetukan Kategori

\begin{tabular}{|c|c|c|}
\hline \multirow{2}{*}{ Skala } & \multicolumn{2}{|c|}{ Kategori } \\
\cline { 2 - 3 } & $\begin{array}{c}\text { Model } \\
\text { Pembelajara } \\
\text { n Think Pair } \\
\text { Share }\end{array}$ & $\begin{array}{c}\text { Kemampua } \\
\text { n } \\
\text { Pemecahan } \\
\text { Masalah } \\
\text { Matematika }\end{array}$ \\
\hline \multirow{7}{*}{} & Kurang & Kurang \\
\hline & Cukup & Cukup \\
\hline & Baik & Baik \\
\hline & Sangat Baik & Sangat Baik \\
& & \\
\hline
\end{tabular}


Keterangan :

X : Variabel Yang Diteliti

Mean : Rata-Rata Ideal

)

SD : Standar Deviasi Ideal

$(\longrightarrow)$

Uji prasyarat meliputi uji normalitas dan uji linieritas.

Uji hipotesis meliputi analisis korelasi, analisis regresi dan koefisien determinasi.

Dan hipotesis yang akan diuji dalam peneltian ini adalah :

: Tidak Terdapat Pengaruh yang signifikan Model Pembelajaran Kooperatif Tipe Think Pair Share Terhadap Kemampuan Pemecahan Masalah Matematika Siswa Kelas VIII MTs Al-Khairiyah Pipitan.

: Terdapat Pengaruh Yang Signifikan Model Pembelajaran Kooperatif Tipe Think Pair Share Terhadap Kemampuan Pemecahan Masalah Matematika Siswa Kelas VIII MTs Al-Khairiyah Pipitan.

\section{HASIL DAN PEMBAHASAN}

\section{Hasil Penelitian}

a. Deskripsi Data

Hasil perhitungan variabel Model Pembelajaran Kooperatif Tipe Think Pair Share diperoleh nilai tertinggi sebesar 97, nilai terendah 72 , mean 85,36 , median 84,18 , modus 82,3 , varians 45,61 dan standar deviasi 6,75.

Berdasarkan hasil perhitungan diperoleh nilai maksimum sebesar 97 sedangkan nilai maksimum idealnya adalah 100. Nilai minimum sebesar 72 sedangkan nilai minimum idealnya adalah 20. Mean yang diperoleh sebesar 85,36 sedangkan mean idealnya adalah 60 . Standar deviasi yang diperoleh sebesar 6,75 sedangkan standar deviasi idealnya adalah 13,3. Berdasarkan mean dan standar deviasi ideal tersebut maka dapat dilakukan pengkategorian variabel model pembelajaran kooperatif tipe think pair share, dalam tabel berikut ini:

Tabel 2.

Kategori Dan Persentase Variabel Model Pembelajaran

Kooperatif Tipe Think Pair Share

\begin{tabular}{|c|c|c|c|c|}
\hline $\begin{array}{c}\text { N } \\
\text { o }\end{array}$ & $\begin{array}{c}\text { Kateg } \\
\text { ori }\end{array}$ & $\begin{array}{c}\text { Interv } \\
\text { al }\end{array}$ & $\begin{array}{c}\text { Frekue } \\
\text { nsi }\end{array}$ & $\begin{array}{c}\text { Persent } \\
\text { ase }\end{array}$ \\
\hline 1 & $\begin{array}{c}\text { Kuran } \\
\text { g baik }\end{array}$ & $\begin{array}{c}20 \leq \\
\mathrm{X} \leq \\
40,05\end{array}$ & 0 & $0 \%$ \\
\hline 2 & $\begin{array}{c}\text { Cukup } \\
\text { baik }\end{array}$ & $\begin{array}{c}40,05 \\
<\mathrm{X} \leq \\
60\end{array}$ & 0 & $0 \%$ \\
\hline 3 & baik & $\begin{array}{c}60< \\
\mathrm{X} \leq\end{array}$ & 4 & $14 \%$ \\
& & $\begin{array}{c}79,95 \\
79,9\end{array}$ & 24 & $86 \%$ \\
\hline 4 & $\begin{array}{c}\text { Sangat } \\
\text { baik }\end{array}$ & $\begin{array}{c}7<\mathrm{X} \\
\leq 100\end{array}$ & & \\
\hline \multicolumn{6}{|c|}{ Total } & 28 & $100 \%$ \\
\hline
\end{tabular}

Berdasarkan distribusi frekuensi variabel model pembelajaran kooperatif tipe think pair share dapat digambarkan dalam diagram batang sebagai berikut.
Model Pembelajaran Kooperatif Tipe Think Pair Share

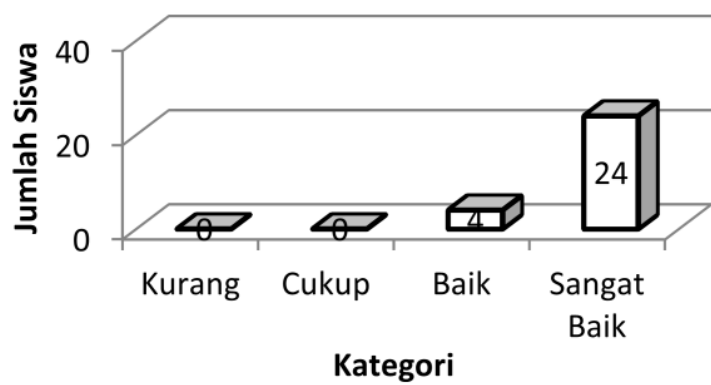

Gambar 4.

\section{Diagram Batang Hasil Penelitian \\ Variabel Model Pembelajaran \\ Kooperatif Tipe Think Pair Share}

Berdasarkan tabel 2 dan gambar 1, diketahui bahwa siswa merespon model pembelajaran kooperatif tipe think pair share pada kategori sangat baik. dengan jumlah responden sebanyak 24 siswa (86 
$\%), 4$ siswa dalam kategori baik (14\%), sedangkan 0 siswa dalam kategori cukup baik $(0 \%)$ dan 0 siswa dalam kategori kurang baik (0 \%). Hal ini menunjukan bahwa siswa merespon model pembelajaran kooperatif tipe think pair share dalam kategori sangat baik karena dalam diagram tersebut menunjukkan bahwa frekuensinya paling banyak.

Hasil perhitungan variabel Kemampuan Pemecahan Masalah Matematika diperoleh skor tertinggi 90, skor terendah 40, mean sebesar 67,78, median 68,86 , modus 69,5 varians 144,52 , dan standar deviasi sebesar 12,02.

Berdasarkan hasil perhitungan diperoleh nilai maksimum sebesar 90 sedangkan nilai maksimum idealnya adalah 100. Nilai minimum sebesar 40 sedangkan nilai minimum idealnya adalah 0 . Mean yang diperoleh sebesar 67,78 sedangkan mean idealnya adalah 50 . Standar deviasi yang diperoleh sebesar 12,02 sedangkan standar deviasi idealnya adalah 16,7. Berdasarkan mean dan standar deviasi ideal tersebut maka dapat dilakukan pengkategorian variabel kemampuan pemecahan masalah matematika, dalam tabel berikut ini :

Tabel 3.

Kategori Dan Persentase Variabel Kemampuan Pemecahan Masalah Matematika

\begin{tabular}{|c|c|c|c|c|}
\hline $\begin{array}{c}\mathbf{N} \\
\text { o }\end{array}$ & $\begin{array}{c}\text { Kateg } \\
\text { ori }\end{array}$ & $\begin{array}{c}\text { Inter } \\
\text { val }\end{array}$ & $\begin{array}{c}\text { Frekue } \\
\text { nsi }\end{array}$ & $\begin{array}{c}\text { Persent } \\
\text { ase }\end{array}$ \\
\hline 1 & $\begin{array}{c}\text { Kuran } \\
\text { g baik }\end{array}$ & $\begin{array}{c}0 \leq \mathrm{X} \\
\leq \\
24,95\end{array}$ & 0 & $0 \%$ \\
\hline 2 & $\begin{array}{c}\text { Cukup } \\
\text { baik }\end{array}$ & $\begin{array}{c}24,95 \\
<\mathrm{X} \leq \\
50\end{array}$ & 2 & $8 \%$ \\
\hline 3 & baik & $\begin{array}{c}50< \\
\mathrm{X} \leq\end{array}$ & 20 & $71 \%$ \\
\hline 4 & $\begin{array}{c}\text { Sangat } \\
\text { baik }\end{array}$ & $\begin{array}{c}75,05 \\
75,05 \\
\mathrm{X} \leq \\
100\end{array}$ & 6 & $21 \%$ \\
\hline
\end{tabular}

(C) 2020, Tulip, Jurnal STKIP Banten p-ISSN : 2338-6126

\begin{tabular}{|c|c|c|}
\hline Total & 28 & $100 \%$ \\
\hline Berdasarkan distribusi & frekuensi
\end{tabular}

variabel kemampuan pemecahan masalah matematika dapat digambarkan dalam diagram batang sebagai berikut :

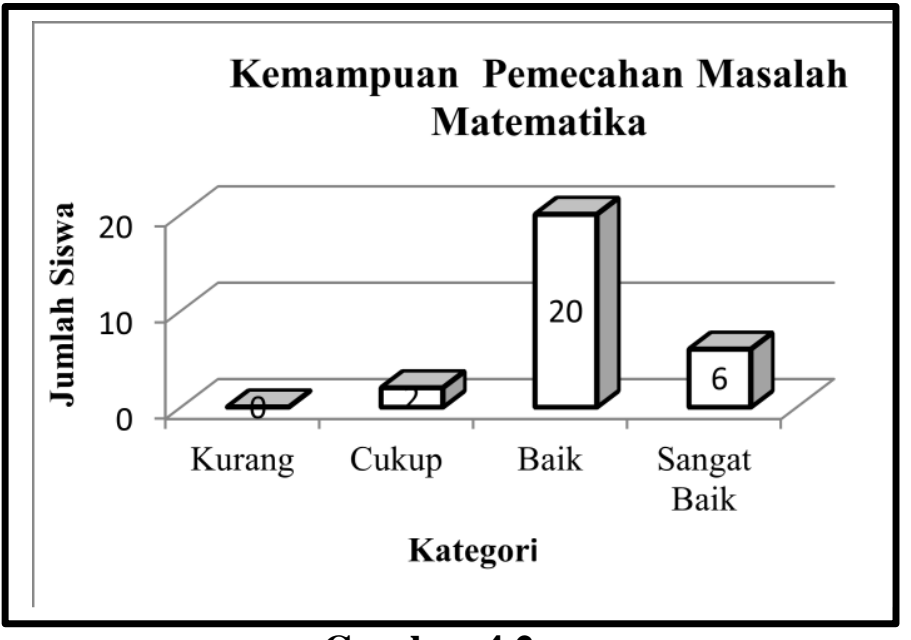

Gambar 4.2

Diagram Batang Hasil Penelitian

Variabel Kemampuan Pemecahan Masalah Matematika

Berdasarkan tabel 3. dan gambar 2, diketahui bahwa kemampuan siswa dalam memecahkan masalah dalam kategori baik. dengan jumlah responden sebanyak 6 siswa dalam kategori sangat baik (21\%), 20 siswa dalam kategori baik (71 \%), sedangkan 2 siswa dalam kategori cukup baik $(8 \%)$ dan 0 siswa dalam kategori kurang baik $(0 \%)$. Hal ini menunjukan bahwa kemampuan siswa kelas VIII MTs Al-Khaeriyah Pipitan Kota Serang dalam memecahkan masalah matematika dalam kategori baik karena dalam diagram tersebut menunjukkan bahwa frekuensinya paling banyak.

\section{b. Uji Pra Syarat}

Berdasarkan perhitungan dari hasil uji normalitas angket diperoleh ${ }^{2}$ hitung $=$ 5,86 dan ${ }_{\text {tabel }}^{2}$ untuk $=0,05=12,59$. Karena 2 hitung $<2$ tabel, maka dapat disimpulkan data dari hasil angket respon siswa berasal dari data yang berdistribusi normal. Selanjutnya Dari perhitungan hasil 
uji normalitas tes diperoleh ${ }^{2}$ hitung $=2,88$ $\operatorname{dan}_{2}{ }_{\text {tabel }}^{2}$ untuk $_{2}=0,05=12,59$. Karena ${ }^{2}$ hitung $<2$ tabel, maka dapat disimpulkan data dari hasil tes berasal dari data yang berdistribusi normal. Hasil perhitungan $\begin{array}{r}\text { linieritas } \\ \text { dan dengan }\end{array}$
diperoleh
yang di peroleh dengan dk pembilang $=\mathrm{k}-2=17-2=15 \mathrm{dan} \mathrm{dk}$ penyebut $=\mathrm{n}-\mathrm{k}=28-17=11$ serta taraf signifikan $=0,05$.

didasarkan pada kriteria pengujian Jika berarti data berpola linier.

karena atau

dapat ditarik kesimpulan bahwa data hasil survei berpola linier.

\section{c. Uji Hipotesis}

Analisis korelasi dilakukan untuk mencari hubungan dan membuktikan hipotesis hubungan dua variabel. analisis korelasi yang digunakan adalah korelasi pearson product moment. Dari hasil perhitungan data hasil survei diperoleh koefisien korelasi 0,522, dapat dilihat pada tabel menunjukan bahwa koefisien korelasi $\mathrm{r}$ berada pada interval 0,40 - 0,599 yang artinya memiliki korelasi atau hubungan sedang.

Analisis regresi dilakukan untuk menentukan persamaan regresi serta membuktikan signifikan atau tidak berdasarkan uji F. Dengan $r$ sebesar 0,522, diketahui persamaan regresi

Hasil perhitungan uji signifikansi analisis regresi diperoleh dan berdasarkan tabel distribusi $\mathrm{F}$ untuk $=0,05$ dengan $\mathrm{dk} \operatorname{Reg}[]=\mathrm{k}-1$, dimana $\mathrm{k}$ menunjukan jumlah variabel bebas dan terikat $=2-1=1 \mathrm{dan} \mathrm{dk}$ Res $=$ $\mathrm{n}-\mathrm{k}=28-2=26$

didasarkan pada kriteria

9,72> 4,22 maka artinya signifikan.

Dengan koefisien korelasi 0,522 diperoleh koefesien determinasi sebesar $27,25 \%$, Dapat disimpulkan bahwa model pembelajaran kooperatif tipe think pair

(C) 2020, Tulip, Jurnal STKIP Banten

p-ISSN : 2338-6126 share berpengaruh terhadap kemampuan pemecahan masalah matematika siswa kelas VIII MTs Al-Khairiyah Pipitan sebesar $27,25 \%$, dan $72,75 \%$ dipengaruhi oleh faktor luar lainya.

\section{Pembahasan}

Dengan selesainya pengujian hipotesis, kita bisa mengetahui apakah terdapat pengaruh model pembelajaran kooperatif tipe think pair share terhadap kemampuan pemecahan masalah matematika.

Berdasarkan hasil analisis deskriptif diketahui siswa sangat antusias dengan menerapkan model pembelajaran kooperatif tipe think pair share dalam belajar matematika. Hal ini di dasarkan pada hasil pengkategorian data angket dimana diketahui bahwa jumlah responden 24 siswa dalam kategori sangat baik (86 $\%), 4$ siswa dalam kategori baik (14\%), kategori cukup baik dengan jumlah responden sebanyak 0 siswa $(0 \%)$, dan 0 siswa dalam kategori kurang baik $(0 \%)$.

Hal ini menunjukan bahwa respon siswa terhadap model pembelajaran kooperatif tipe think pair share termasuk dalam kategori sangat baik, karena berdasarkan keterangan tersebut menunjukan bahwa frekuensinya paling banyak.

Selanjutnya hasil analisis deskriptif penelitian menegenai variabel kemampuan pemecahan masalah matematika diketahui bahwa mayoritas siswa kelas VIII MTs Alkhaeriyah Pipitan Kota Serang memiliki kemampuan pemecahan masalah matematika dalam kategori baik. Hal ini di dasarkan pada hasil pengkategorian data tes dimana diketahui bahwa jumlah responden 6 siswa dalam kategori sangat baik (21\%), 20 siswa dalam kategori baik (71 \%), 2 siswa dalam kategori cukup (8 $\%$ ), sedangkan 0 siswa dalam kategori sangat kurang $(0 \%)$.

Hal ini menunjukan bahwa kemampuan siswa kelas VIII MTs Alkhaeriyah Pipitan Kota Serang dalam 
memecahkan masalah matematika dalam kategori baik, karena berdasarkan keterangan tersebut menunjukan bahwa frekuensinya paling banyak.

Berdasarkan penelitian yang dilakukan, model pembelajaran kooperatif tipe think pair share berpengaruh terhadap kemampuan pemecahan masalah matematika, hal tersebut dapat diketahui melalui uji hipotesis dengan menggunakan analisis korelasi dan analisis regresi. Melalui analisis korelasi dapat diketahui besar koefisien korelasi variabel bebas terhadap variabel terikat, hasil perhitungan diperoleh besar koefisien korelasi sebesar $=0,522$. Besar $=0,522$ termasuk dalam kategori sedang.

Selanjutnya hasil perhitungan menggunakan analisis regresi sederhana, diketahui persamaan regresi dengan $r$ sebesar 0,522, membentuk persamaan regresi . Selanjutnya hasil perhitungan uji signifikansi diketahui nilai sebesar 9,72. dan

\section{Karena yang artinya \\ signifikan dengan $=0,522$ di peroleh} koefisien determinasi sebesar 27,25 \%. Jadi sisanya sebesar $72,75 \%$ adalah faktor variabel lainnya yang tidak di teliti dalam penelitian ini.

Berdasarkan hasil penelitian ini, maka dapat dinyatakan bahwa model pembelajaran kooperatif tipe think pair share merupakan salah satu faktor yang mempengaruhi kemampuan pemecahan masalah matematika siswa kelas VIII MTs Al-Khairiyah Pipitan Kota Serang, sehingga jika guru sering menggunakan model pembelajaran kooperatif tipe think pair share dalam pembelajaran matematika maka ada kemungkinan kemampuan siswa dalam memecahkan masalah matematika semakin baik.

Hasil penelitian tersebut sejalan dengan teori yang disampaikan oleh evelin bahwa pembelajaran kooperatif merupakan model pembelajaran yang menekankan aktivitas kolaboratif siswa dalam belajar yang memecahkan masalah secara kolektif kolaboratif (Eveline Siregar dan Hartini Nara, 2010). Yang artinya dengan pembelajaran kooperatif siswa akan memecahkan masalah secara bersamasama. Dimana dengan kerja kelompok siswa akan lebih banyak mendapatkan masukan-masukan dalam memecahkan masalah, yang pada akhirnya siswa akan mampu secara mandiri dalam memecahkan masalah. Selanjutnya Nurhadi dalam Reni menyatakan think pair share merupakan struktur pembelajaran yang dirancang untuk mempengaruhi pola interaksi siswa agar tercipta suatu pembelajaran kooperatif yang dapat meningkatkan penguasaan akademik dan keterampilan siswa (Reni Astuti, 2018) Jelas bahwa dengan menerapkan model pembelajaran think pair share akan mempengaruhi siswa dalam meningkatkan pengusaan akademik dan salah satunya yaitu kemampuan dalam memecahkan masalah.

\section{PENUTUP}

\section{Simpulan}

Berdasarkan hasil penelitian yang sudah peneliti paparkan pada bab sebelumnya, peneliti berkesimpulan bahwa terdapat pengaruh yang signifikan dari model pembelajaran kooperatif tipe think pair share terhadap kemampuan pemecahan masalah matematika siswa kelas VIII MTs Al-Khairiyah Pipitan Kota Serang.

\section{Saran}

Berdasarkan hasil penelitian yang telah di dapatkan maka saran yang dapat di sampaikan oleh peneliti adalah bagi peneliti lain hasil survai pengaruh model pembelajaran kooperatif tipe think pair share terhadap kemampuan pemecahan masalah matematika siswa ternyata masih banyak dipengaruhi oleh faktor lain yang mempengaruhi kemampuan pemecahan masalah matematika. Oleh karena itu, 
kiranya perlu dikembangkan penelitian berikutnya untuk mengetahui bagaimana kemampuan pemecahan masalah matematika siswa dari aspek lainnya. Bagi siswa agar dapat mengikuti proses pembalajaran dengan baik, dalam rangka mengembangkan kemampuan pemecahan masalah matematika dengan adanya model pembelajaran kooperatif tipe think pair share Share. Siswa secara lebih aktif, kreatif, secara mandiri dalam menerima dan mengolah materi pembelajaran dengan baik yang di berikan oleh guru sehingga dapat berpengaruh terhadap hasil belajar. Bagi sekolah agar hasil survei ini dapat menjadi solusi alternativ sekolah dalam mengembangkan kemampuan pemecahan masalah matematika siswa yaitu dengan menerapkan model pembelajaran kooperatif tipe think pair share.

\section{DAFTAR PUSTAKA}

Dimyati \& Mudjiono. (2013). Belajar dan Pembelajaran. Jakarta: Rineka Cipta

E. Mulyasa. (2016). Menjadi Guru

Profesional. Bandung: PT Remaja

Rosdakarya

Eka Lestari, Kurnia dan Ridwan Yudhanegara, Mochammad. (2017). Penelitian Pendidikan Matematika. Bandung: Refika Aditama

Halim Fathani, Abdul. (2016). Matematika Hakikat dan Logika. Yogyakarta: Ar-Ruzz Media

Huda, Miftahul. (2017). Model-model Pengajaran dan Pembelajaran. Yogyakatya: Pustaka Pelajar

Ihsan, Fuad. (2011). Dasar-dasar Kependidikan. Jakarta: PT Rineka Cipta

Rusman. (2016). Model-model Pembelajaran Mengembangkan Profesionalisme Guru. Jakarta: PT Raja grafindo Persada

Sagala, Syaiful. (2012). Konsep dan Makna Pembelajaran. Bandung: Alfabeta

Shoimin, Ariz. (2013). 68 Model Pembelajaran inovatif dalam kurikulum 2019. Yogyakarta: Ar-ruz Media

Siregar, Eveline dan Nara, Hartini. (2010). Teori Belajar dan Pembelajaran. Bogor: Ghalia Indonesia

Sugiyono. (2017). Metode Penelitian Kuantitatif, Kualitatif dan $R \& D$. Bandung: Alfabeta

Suprijono, Agus. (2017). Cooperative Learning Teori \& Aplikasi PAIKEM. Yogyakarta. Pustaka Pelajar
Susanto, Ahmad. (2016). Teori Belajar dan Pembelajaran di Sekolah Dasar. Jakarta: Prenademedia Group

Wena, Made. (2013). Strategi Pembelajaran Inovatif Kontemporer Suatu Tinjauan Konseptual Operasional. Jakarta: Bumi Aksara

Ratna Latifah Jati. (2015). Pengaruh Kekuatan Guru Terhadap Motivasi Belajar Siswa Kelas V SD Negri Segugus Siropti Kecamatan Grabag Kabupaten Magelang. Skripsi PSGD. Universits Negeri Yogyakarta. Tidak diterbitkan

Reni Astuti. (2018). Pengaruh Model Pembelajaran Kooperatif Tipe Think Pair Share (TPS) Terhadap Kemampuan Pemahaman Konsep Matematis Siswa. Skripsi Pendidikan Matematika. Universitas Lampung. Tidak diterbitkan

Agus Margono, Budiono dan Imam Sujadi. (2017).

Eksperimentasi Model Pembelajaran Kooperatif Tipe Teams Games Tournament dan Numbered Heads Together Ditinjau dari Kecerdasan Emosional Siswa. Jurnal Ilmiah Guru "COPE" Vol.2 No.2. Universitas Sebelas Maret Surakarta

Ahmad Yamin Hasibuan. (2016). Pengaruh Model Pemelajaran Think Pair Share Terhadap Kemampuan Memahami Unsur Interistik Cerpen Pada Siswa Kelas X SMA Negeri Padangsidimpuan. Jurnal Dosen Vol.1 No.1. UMTS

Ali Rohali. (2018). Upaya Meningkatkan Kinerja Guru Dalam Menerapkan Model Pembelajaran Kooperatif Numbered Head Together Pada Sekolah Binaan SMP Kecamatan Kelam Permai. Jurnal Pendidikan Dasar Perkhasa Vol.4 No.1. Dinas Pendidikan dan Kebudayaan Kabupaten Siantang

Andi Khaerunnisa Hardyanti Arki, Amry Auliyah, Iwan Dini. (2017). Penerapan Metode Pembelajaran Kooperatif Tipe Think-PairShare Untuk Meningkatkan Hasil Belajar SiswaKelas XI mia.2 SMA Negeri 3 Model Takalar (Studi Pada Materi Pokok Larutan Asam Basa). Jurnal Cemical Vol.18 No.2. Universitas Negri Makasar

Asep Sahrudin. (2016). Implementasi Model Pembelajaran Means-Ends Analysis untuk Meningkatkan Kemampuan Pemecahan Masalah Matematika Mahasiswa. Jurnal Pendidikan UNISKA Vol.4 No.1. Universitas Mathla'ul Anwar

Indra Sakti. (2011). Korelasi Pengetahuan Alat Praktikum Fisika dengan Kemampuan Psikomotorik Siswa di SMA Negeri Kota Bengkulu. Jurnal Exacta Vol.IX No.1. Universitas Bengkul 
Kartika Handayani Z. (2017). Analisis FaktorFaktor Yang Mempengaruhi Kemampuan Pemecahan Masalah Soal Cerita Matematika. Jurnal Semnastika Unimed ISBN: 978-602-17980-9-6. Universitas Negeri Medan

Nurul Badriaytul Muthoharoh. (2017). Pengaruh Model Pembelajaran Kooperatif Think Pair Share (TPS) Terhadap Hasil Belajar Bahasa Inggris. Jurnal SAP Vol.2 No.1. Universitas Indaraprasta PGRI

Shanty Della Setiasih, Regina Lichteria Panjaitan, Julia. (2016). Penggunaan Model Inquiri Untuk Meningkatkan Hasil Belajar Siswa Pada Materi Sifat-Sifat Magnet Di Kelas V SDN Sukajaya Kecamatan Jatinunggal Kabupaten Sumedang. Jurnal Pena Ilmiah Vol.1 No.1. Universitas Pendidikan Indonesia Sumedang

Siti Komariyah, Dian Septi Nur Afifah, Gaguk Resbiantoro. (2018).Analisis Pemahaman Konsep Dalam Memecahkan Masalah Matematika Ditinjau Dari Minat Belajar Siswa. Jurnal Sosiohumaniora Vol.4 No.1. Universitas Sarjanawiyata Taman siswa Yogyakarta

Suryo Widodo. (2017). Menghasilkan Lulusan Kreatif Melalui Pembelajaran Berbasis Masalah Kontekstual. Jurnal Math Edukator Nusantara Vol.3 No.2. Universitas Nusantara PGRI Kediri

Susanti. (2017). Meningktkan Hasil Belajar Ekonomi Dengan Model Pembelajaran Think Pair Share (TPS) Siswa kelas X MAN Peusangan.Jurnal Sains Ekonomi dan Edukasi Vol.5 No.1. Universitas Almuslim

Ahmad Rifai. Tujuan Pembelajaran Matematika. diakses pada tanggal 19 Februari 2020 pukul 19.30 WIB. tersedia: ahmadrifai-noor. blogspot.com/2016/03/tujuan-pembelajaranmatematika-ktsp-2006.html

Nidhomuddin. Pembelajaran Kooperatif Cooperative Learning. diakses pada tanggal 17 Februari 2020 pukul 20.05 WIB. tersedia: https://nidhomuddin01.wordpress.com/2013 /01/10/Pembelajaran kooperatifcooperative-learning/\#_ftn20

Sahurikhorot. Pembelajaran Kooperatif. Diakses Pada Tanggal 13 April 2020 Pukul 22.40 WIB.

Tersedia:http://Sahurikohort.Blogspot.Com/ 2015/09/ Artikel.Html

Zulfikarmansyur. Kemampuan Pemecahan Masalah Matematis. diakses pada tanggal 29 Oktober 2019 pukul 17.29 WIB. tesedia: https://zulfikarmansyur.wordpress.com/2014 /01/07/13/

(C) 2020, Tulip, Jurnal STKIP Banten

p-ISSN : $2338-6126$ 